\title{
THE EFFECT OF PLANT VOLATILES ON PLANT PREFERENCE BY THE PREDATORY INSECT, Sycanus dichotomus STAL. (Hemiptera: Reduviidae) IN OIL PALM PLANTATION
}

\author{
SYARI JAMIAN*; NUR AZURA ADAM*; HAFIDZI MOHD NOOR*; DZARIFAH ZULPERI; NORHAYU \\ ASIB*; RITA MUHAMAD*; ANIS SYAHIRAH MOKHTAR*; MOHD AS'WAD ABDUL WAHAB*; BADRUL \\ AZHAR $^{\star \star} ;$ MOGERET SIDI* and AZMAN MAAMOR ${ }^{\ddagger}$
}

\begin{abstract}
A study of choice test and no-choice test was conducted to test plant volatiles response to adult orientation behaviour and performance of predatory insect, Sycanus dichotomus on three beneficial plants (Turnera subulata, Antigonon leptopus and Cassia cobanensis) and three ground vegetation covers (Asystasia gangetica, Euphorbia heterophylla and Ageratum conyzoides). Gas chromatography-mass spectrometry (GC-MS) was used to determine the number of volatile compounds in the beneficial plants extracts, namely Trimethyl-3,4-methylenedioxychromane, Phenol,4,6-di(1,1-dimethylethyl)-2-methyl, 2H-1-Benzopyran,6,7-dimethoxy-2,2-dimethyl-, n-Hexadecanoic acid, Dodecanoic acid, 3-hydroxy-, Octadecanoic acid, and 2-(2-hydroxyethoxy) ethyl ester and to confirm the most preferred plant by the predatory insect. We recommend further investigation on the efficiency of various beneficial plants in relation to the activities of $\mathrm{S}$. dichotomus.
\end{abstract}

Keywords: Sycanus dichotomus, beneficial plants, host finding, plant volatiles, GC-MS.

Date received: 21 May 2019; Sent for revision: 28 June 2019; Accepted: 30 September 2019; Available online: 3 September 2020.

\section{INTRODUCTION}

Conservation and distribution of natural enemies of insects (predators and parasitoids) in oil palm plantation suppress pests while pollinators increase crop yields. Many beneficial insects rely on useful plants for nectar and pollen or shelter (Jamian et al., 2017). Plants that are commonly recommended

\footnotetext{
Department of Plant Protection

Faculty of Agriculture, Universiti Putra Malaysia,

43400 UPM Serdang, Selangor, Malaysia.

E-mail: syari@upm.edu.my

** Department of Forest Science and Biodiversity, Faculty of Forestry and Environment, Universiti Putra Malaysia, 43400 UPM Serdang, Selangor, Malaysia.

₹ Chemistry Department, Faculty of Science, Universiti Malaya, 50603 Kuala Lumpur, Malaysia
}

to provide these resources are non-native annuals such as Turnera subulata, Antigonon leptopus and Cassia cobanensis and these plants are actively being implemented by planters to sustain the population of natural enemies (Norman and Basri, 2007). Besides that, beneficial plants can be crucial in providing alternative food (nectar and pollen) and habitat for beneficial insects (Basri and Kevan, 1995). Many predatory insects, pests and parasites use flower nectar as a source of energy while they search for prey (Yusdayati et al., 2014).

Currently, effective control measures of bagworms comprise of different chemical insecticides. In Malaysia, trunk injection technique using monocrotophos and methamidophos is the most popular control method to control pest of oil palm aged six years old and above in Felda plantations (Noor Hisham and Sukri, 2004). 
Although the usage of insecticides is successful in controlling pests (Wood and Nesbit, 1969; Sing, 1986; Chung, 1989), extensive usage can annihilate natural enemy population and consequently encourages pests resurgence that can lead to pest outbreak (Leena and Hazem, 2011). However, Noor Farehan et al. (2013) highlighted that cypermethrin, deltamethrin and trichlorfon are the prominent compounds that caused high mortality against insect predators. Commonly, natural enemies of bagworms such as predators and parasitoids are abundantly available on beneficial plants (Ho et al., 2003; Norman and Basri, 2010; Jamian et al., 2017). Strategic use of flowering plants to increase plant biodiversity in a targeted manner can provide natural enemies with shelter and food source to enhance biological control and reduce dependence to chemical pesticides. Therefore, the propagation and abundance of natural enemies are strongly dependent on the availability of suitable beneficial plants as sources of nectar (Norman and Basri, 2010). Planting of beneficial plants such as $T$. subulata, C. cobanensis and A. leptopus were adopted in oil palm plantation to provide food and shelter to many natural enemies particularly predators and parasitoids (Ho, 2002).

Predators and parasitoids need the plants and flowers that provide moisture, shelter, alternative prey and immediate nutrition from nectar and pollen. Floral nectar composition is vital in species pollination system and relationship with potential pollination vectors (Heil, 2011). Different groups of animals will have different physiology and nutritive requirements; therefore, the composition of sugars and amino acids in nectar is usually highly correlated with the specific nutritive requirements of a flower's pollinators (Gonzalez-Teuber and Heil, 2009). Besides that, by manipulating the habitat of floral resources in agroecosystem, it could provide additional food for beneficial insects and potentially enhancing their fitness and efficacy. Nutrients such as carbohydrate-rich nectars are believed to provide energy, and pollens, may provide nutrients for egg production in some species (Jervis et al., 1996) and longevity of parasitoids (Basri et al., 1999).

Nevertheless, flower may attract beneficial insects through the released chemicals. Liu et al. (2013) reported that flowers of Mucuna sempervirens produce nectar whose composition include sugars, proteins, phenolics, hydrogen peroxide and aromatic compounds. While, the flowering plants namely $C$. cobanensis, Crotalaria usaramoensis, Asystasia gangetica and Euphorbia heterophylla contain nectar composed of sucrose, fructose and glucose (Basri et al., 1999). Many predators and parasitoids are attracted to flowering plants, where they obtain pollens and nectars that help to increase their longevity and ability to lay eggs. Jamian and Nur Azura (2018) reported the combination of flowering plants
(T. subulata) and its prey (M. plana) would sustain their longevity and fecundity of predatory insect. We are not aware of any research being carried out on the efficacy of beneficial plants to improve performance of insect predators as potential biocontrol agents in oil palm plantation. Therefore, the aims of this study were: (i) to investigate the efficiency of various beneficial plants towards the activities of $S$. dichotomus, and (ii) to evaluate the nectar content of different type of plants.

\section{MATERIALS AND METHODS}

The study was carried out under a controlled environment in the glasshouse of the Faculty of Agriculture, Universiti Putra Malaysia (UPM), Selangor, Malaysia. The glasshouse had 12:12 hr day:night photoperiod, $21^{\circ} \mathrm{C}-36^{\circ} \mathrm{C}$ temperature range and relative humidity of 55\%-65\%. Six types of plants were used in this study, namely, T. subulata, A. leptopus, C. cobanensis, Asystasia gangetica, Euphorbia heterophylla and Ageratum conyzoides. Experiment was separated to no-choice and choice test categories.

\section{No-choice and Choice Glasshouse Test}

The tested plants were placed in a cage, (40 $\mathrm{cm} \times 40 \mathrm{~cm} \times 60 \mathrm{~cm}$ ) (Figure 1). The sides and the top were made of transparent perspex, and the base was made of wood. The front of the cage was converted into a door with a dimension of $40 \mathrm{~cm} \times 60 \mathrm{~cm}$ to facilitate access into the cage for introducing the various plants prior to the start of the experiment and for cleaning purposes. A hole of $20 \mathrm{~cm}$ diameter was made at the left and right sides, and on the door, to introduce insect predators. To prevent insect escaping the rearing cage, the holes were equipped with a sleeve of muslin cloth that can be folded. To diffuse the light coming from the ceiling, the top of the cage was covered with a layer of clean plain white paper. For no choice test, five pairs (males and females) of $S$. dichotomus and six types of plants, 2-3 pots per plant were used for $T$. subulata, C. cobanensis, E. heterophylla, A. gangetica, and $A$. conyzoides, except for A. leptopus with only one pot. Each plant type was located in different cages; they were introduced into the cage when they have flowers which were completely opened. Whereas, for the choice test, five pairs (males and females) of $S$. dichotomus and six types of plants were introduced in the same cage $(100 \mathrm{~cm} \times 100$ $\mathrm{cm} \times 170 \mathrm{~cm}$ ). The parameters observed were: (i) the number of predatory insects feeding on nectar or resting on any parts of the plants between 9.00 am-11.00 am for one to four days after introduction into the cage, and (ii) the number of eggs laid. All experiments were replicated 10 times. 

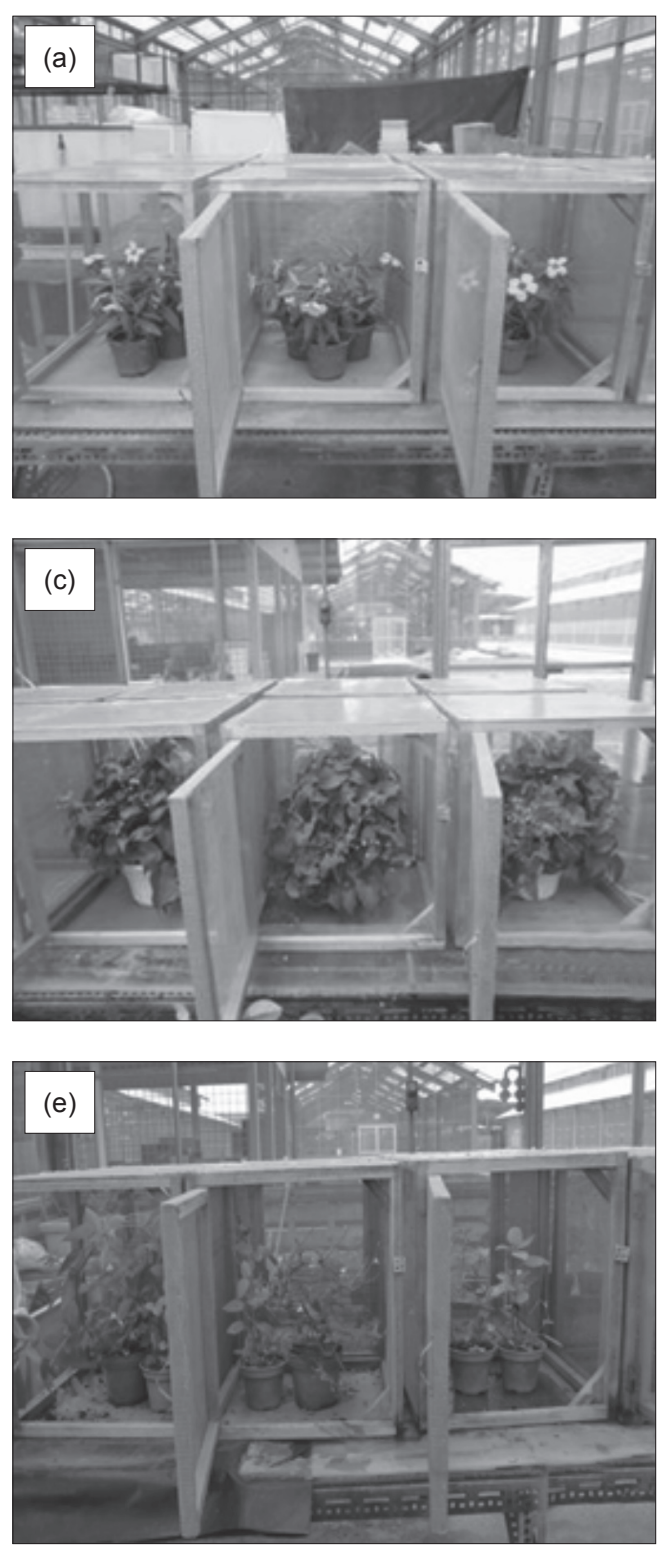
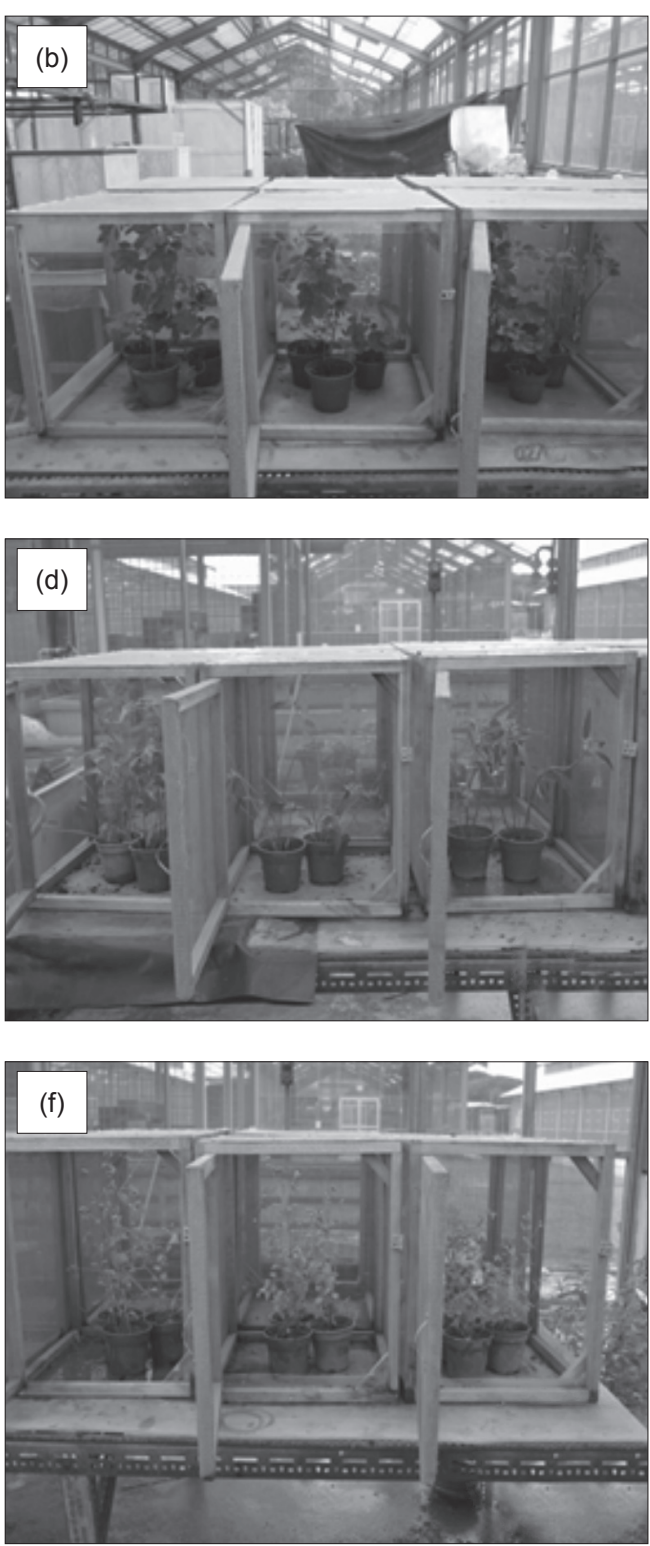

Figure 1. Demographic of plants, (a) T. subulata, (b) C. cobanensis, (c) A. leptopus, (d) E. heterophylla, (e) A. gangetica, and $(f)$ A. conyzoides.

\section{Chemical Composition of Nectars}

Fresh nectars were collected from the six plant species in Field 2 and the Glasshouse Unit at UPM. A wick was used to collect nectars from 10 flowers of T. subulata, A. leptopus, C. cobanensis, A. gangetica, E. heterophylla and A. conyzoides as described by Liu et al. (2013). Collected nectars were extracted using n-hexane solvent by shaking at room temperature for $1 \mathrm{hr}$. The extract was then centrifuged at $12000 \mathrm{rpm}$ for $30 \mathrm{~min}$ at $4^{\circ} \mathrm{C}$ and concentrated under a stream of $\mathrm{N}^{2}$. The extract was analysed using gas chromatography (GC) [Trace EC Ultra, column: $0.25 \mathrm{~mm}$ x $30 \mathrm{~m}$ (TG-5MS)] with temperature programming $80^{\circ} \mathrm{C}$ to $350^{\circ} \mathrm{C}$ at $3^{\circ} \mathrm{C}$ $\mathrm{min}^{-1}$, or to gas chromatography-mass spectrometry (GC-MS) [TSQ Quantum XLS (Trace EC Ultra, column: $0.25 \mathrm{~mm} \times 30 \mathrm{~m}$ ) (TG-5MS)] under the following conditions: electron-impact (EI) mode

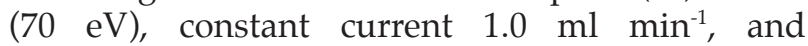
temperature programming from $80^{\circ} \mathrm{C}$ to $240^{\circ} \mathrm{C}$ at $3^{\circ} \mathrm{C} \mathrm{min}^{-1}$. Identification of volatile compounds was performed using $\mathrm{X}$ Calibur 2.1 software for Windows. Peak identification was made by comparing retention times and the mass spectra of eluting compounds to those in the NIST/Wiley database.

\section{Data Analysis}

Obtained data sets of choice and no-choice experiments were subjected to analysis of variance using computer software (MINITAB 14.0 for Windows) statistical package. Treatments with significant differences were compared at $\mathrm{P}=0.05$ level of probability using Tukey's test. 


\section{RESULTS}

In the no-choice test, the duration of exposure to different plants had a pronounced effect on the cumulative mean number of adult predators. The highest number of adult predators were observed on T. subulata, A. leptopus, C. cobanensis and A. conyzoides throughout the four days exposure as shown in Table 1. The number of adult predators at two days exposure time were significantly highest $(\mathrm{P}<0.001)$ on $T$. subulata (3.7 individuals), C. cobanensis (3.3 individuals) and A. leptopus (2.6 individuals) compared to other plants in the treatments. However, it was observed a decline in the number of predators in those plants at Day 3 of exposure. The number of predators on the weed plants ranging from 2.1 to 2.2 (A. gangetica and $E$. heterophylla) was lower compared to the other plants with the exception of Day 3, throughout the study. At Day 4, T. subulata had similar number of predators as A. leptopus, C. cobanensis and $A$. conyzoides but significantly different from $A$. gangetica and E. heterophylla.

The same result was obtained from the choice study where the exposure to different plants had a pronounced effect on the mean number of adult predators. The highest number of adult predators was observed on $T$. subulata and $C$. cobanensis throughout the four days exposure times (Table 2). In this study, the presence of predators after two days on T. subulata (3.0 individuals), A. leptopus (3.0 individuals) and C. cobanensis (2.1 individuals) were observed and they were significantly higher than the other plants (A. gangetica, E. heterophylla and $A$. conyzoides). Although the number of predators declined at Days 3 and 4 of observation, T. subulata and C. cobanensis remained the highest with 2.2 and 2.3 number of predators, respectively. Meanwhile, A. leptopus showed significant declined in the number of predators and the number was lower compared to the weed plants from Days 3 and 4 of observation. In both no-choice and choice tests, there were no eggs produced even though $S$. dichotomus was provided food from nectar. Essential nutrients such as protein and amino acids, lipids, vitamins and mineral are also vital to enhance or optimise growth, development and reproduction.

Based on the results of earlier study, extract of six plants namely $T$. subulata, $C$. cobanensis, A. leptopus, A. gangetica, E. heterophylla and A. conyzoides were included in the next study because they contained high concentration of volatile compounds. From the result, it is shown that about 88 to 92 volatile compounds were identified in the nectar and pollen using GC-MS based on NIST/ Wiley database, respectively. The quantification of identified compounds accounted for $88 \%-92 \%$ of the total volatiles (Table 3). Additional compounds were detected at retention times as shown in Figure 2. They were grouped into four major classes (alkane, alcohol, carboxylic acid and carboxylate ester) based on their biosynthetic origins. None of these four classes was dominant in the six plants.

\section{DISCUSSION}

\section{Number of Predatory Insects}

These findings supported Yusdayati et al. (2014) who reported that diversity and distribution of population of natural enemies can be observed on beneficial plants (C. cobanensis and Turnera spp.) while Norman and Basri (2010) reported that parasitoids and predators are the most abundant on C. cobanensis. However, Ho et al. (2003) reported that the number of parasitoid activities in the field increased with the presence of E. heterophylla and $C$. cobanensis in the field.

Few predatory insects and parasitoids feed on non-prey foods such as pollens and nectar (Hoffman and Frodsham, 1993; Hickman and Wratten, 1996; Kroon, 2009). Predators may be attracted to allelochemicals when released into the environment. Host colour and shape can be important in plant characteristic visual features and for predators that are day flying, although visually mediated responses are usually relatively unspecific (Bernays and Chapman, 1994). Many experiments have shown that the presence of flowers in an agroecosystem can increase the abundance of natural enemies. Results revealed that the tested predator showed strong attraction to the beneficial plant, $T$. subulata and these findings are similar to Yusdayati (2008), who reported that Turnera sp., A. leptopus and C. cobanensis are more favoured by natural enemies. Chaney (1998) highlighted that the number of beneficial insects increased in lettuce in the presence of a range of flowers species. Leaf roller parasitoids, Dolichogenidea tasmanica (Cameron) were found in yellow sticky trap and the number increased when buckwheat flowers were present in an apple orchard (Irvin et al., 2000) and a vineyard (Berndt et al., 2002).

The conducted experiments are the first study in investigating the attraction of predatory insects to beneficial plants namely T. subulata, A. leptopus and $C$. cobanensis and three ground vegetation covers, A. gangetica, E. heterophylla and A. conyzoides. Ho et al. (2003) carried out comprehensive trials to evaluate the efficacy of a range of beneficial plants and the result showed three plant species namely $C$. cobanensis, A. leptopus and T. subulata to be the most effective to attract natural enemies. In addition, $E$. heterophylla is not favoured for planting because of having difficulty to establish and possesses a short life cycle (Ho et al., 2003); and C. cobanensis produces flowers only once a year (Basri et al., 1999). The most 
preferred plant then is Turnera. Schlindwein and Medeiros (2006) has reported that the flowers of $T$. subulata could attract 28 species of insects. Similarly, Barret (1978) has listed as many as 13 species of insects as flower visitors on T. urmifolia. In this study, $S$. dichotomus was indeed very attracted to $T$. subulata. This shows the importance of Turnera as a source of shelter and nectar for $S$. dichotomus and it is suggested to plant it because the flowers are set throughout the year.

TABLE 1. MEAN NUMBER OF ADULT PREDATORS IN NO-CHOICE STUDY AT DIFFERENT EXPOSURE TIMES

\begin{tabular}{|c|c|c|c|c|}
\hline \multirow{2}{*}{ Treatment/exposure time } & \multicolumn{4}{|c|}{ Day } \\
\hline & 1 & 2 & 3 & 4 \\
\hline Cassia cobanensis & $0.0 \pm 0.00^{\mathrm{a}}$ & $3.3 \pm 0.90^{\mathrm{ab}}$ & $2.7 \pm 0.68^{a}$ & $2.8 \pm 1.55^{\mathrm{ab}}$ \\
\hline Antigonon leptopus & $0.0 \pm 0.00^{\mathrm{a}}$ & $2.6 \pm 1.08^{\mathrm{abc}}$ & $2.5 \pm 1.08^{\mathrm{a}}$ & $3.2 \pm 1.48^{\mathrm{ab}}$ \\
\hline Turnera subulata & $0.0 \pm 0.00^{\mathrm{a}}$ & $3.7 \pm 1.40^{\mathrm{a}}$ & $3.3 \pm 0.68^{\mathrm{a}}$ & $4.1 \pm 1.20^{\mathrm{a}}$ \\
\hline Asystasia gangetica & $0.0 \pm 0.00^{\mathrm{a}}$ & $2.2 \pm 0.79^{\mathrm{bc}}$ & $2.8 \pm 1.48^{\mathrm{a}}$ & $2.1 \pm 0.88^{\mathrm{b}}$ \\
\hline Euphorbia heterophylla & $0.0 \pm 0.00^{\mathrm{a}}$ & $1.8 \pm 1.03^{c}$ & $2.2 \pm 1.40^{\mathrm{a}}$ & $2.1 \pm 1.10^{\mathrm{b}}$ \\
\hline Ageratum conyzoides & $0.0 \pm 0.00^{\mathrm{a}}$ & $2.2 \pm 0.79^{\mathrm{bc}}$ & $2.1 \pm 0.88^{\mathrm{a}}$ & $2.6 \pm 1.08^{\mathrm{ab}}$ \\
\hline
\end{tabular}

Note: Means in the column with same letters are not significantly different at $\mathrm{P}=0.05$ level of probability according to Tukey's test.

TABLE 2. MEAN NUMBER OF ADULT PREDATORS IN CHOICE STUDY AT DIFFERENT EXPOSURE TIMES

\begin{tabular}{|c|c|c|c|c|}
\hline \multirow{2}{*}{ Treatment/exposure time } & \multicolumn{4}{|c|}{ Day } \\
\hline & 1 & 2 & 3 & 4 \\
\hline Cassia cobanensis & $0.0 \pm 0.00^{\mathrm{a}}$ & $2.1 \pm 0.32^{\mathrm{b}}$ & $2.3 \pm 0.95^{b}$ & $2.0 \pm 1.16^{\mathrm{b}}$ \\
\hline Antigonon leptopus & $0.0 \pm 0.00^{\mathrm{a}}$ & $3.0 \pm 0.48^{b}$ & $0.5 \pm 0.71^{\mathrm{a}}$ & $0.0 \pm 0.00^{\mathrm{a}}$ \\
\hline Turnera subulata & $0.0 \pm 0.00^{\mathrm{a}}$ & $3.0 \pm 1.50^{\mathrm{b}}$ & $2.2 \pm 1.03^{b}$ & $2.0 \pm 0.67^{\mathrm{b}}$ \\
\hline Asystasia gangetica & $0.0 \pm 0.00^{\mathrm{a}}$ & $0.0 \pm 0.00^{\mathrm{a}}$ & $0.2 \pm 0.42^{\mathrm{a}}$ & $0.4 \pm 0.52^{a}$ \\
\hline Euphorbia heterophylla & $0.0 \pm 0.00^{\mathrm{a}}$ & $0.4 \pm 0.52^{\mathrm{a}}$ & $0.8 \pm 0.79^{a}$ & $0.8 \pm 0.42^{a}$ \\
\hline Ageratum conyzoides & $0.0 \pm 0.00^{\mathrm{a}}$ & $0.2 \pm 0.42^{\mathrm{a}}$ & $0.0 \pm 0.00^{\mathrm{a}}$ & $0.4 \pm 0.52^{a}$ \\
\hline
\end{tabular}

Note: Means in the column with same letters are not significantly different at $\mathrm{P}=0.05$ level of probability according to Tukey's test.

TABLE 3. COMPOSITION OF HOST PLANTS FLORAL VOLATILES FROM SIX CULTIVAR BY GAS CHROMATOGRAPHY-MASS SPECTROMETRY (GC-MS)

\begin{tabular}{|c|c|c|c|c|c|c|}
\hline \multirow{2}{*}{ Compounds } & \multicolumn{6}{|c|}{ Number of compounds } \\
\hline & $\mathrm{AC}$ & AG & TS & $\mathrm{CC}$ & EH & AL \\
\hline Alcohol & 10 & 12 & 15 & 15 & 18 & 11 \\
\hline Carboxylate ester & 12 & 19 & 9 & 19 & 14 & 22 \\
\hline Alkane & 14 & 21 & 15 & 25 & 30 & 17 \\
\hline Alkene & 13 & 3 & 5 & 5 & 4 & 7 \\
\hline Carboxylic acid & 19 & 25 & 28 & 12 & 19 & 19 \\
\hline Alkyne & 1 & 1 & 3 & 1 & 1 & 3 \\
\hline Aldehye & 2 & 1 & 1 & 1 & 0 & 1 \\
\hline Amine & 2 & 1 & 0 & 1 & 1 & 1 \\
\hline Carboxylate salt & 0 & 2 & 0 & 0 & 0 & 0 \\
\hline Ester & 2 & 0 & 0 & 0 & 0 & 0 \\
\hline Ether & 0 & 0 & 0 & 1 & 0 & 1 \\
\hline Ketone & 4 & 1 & 2 & 3 & 2 & 3 \\
\hline Organosilicone & 2 & 1 & 1 & 0 & 0 & 1 \\
\hline Salt & 5 & 2 & 10 & 8 & 1 & 2 \\
\hline Unknown & 2 & 0 & 1 & 1 & 0 & 2 \\
\hline Total & 88 & 89 & 90 & 92 & 90 & 90 \\
\hline
\end{tabular}

Note: AC - Ageratum conyzoides.

CC - Cassia cobanensis.

AG - Asystasia gangetica.

EH - Euphorbia heterophylla.

TS - Turnera subulata.

AL - Antigonon leptopus. 
(a)

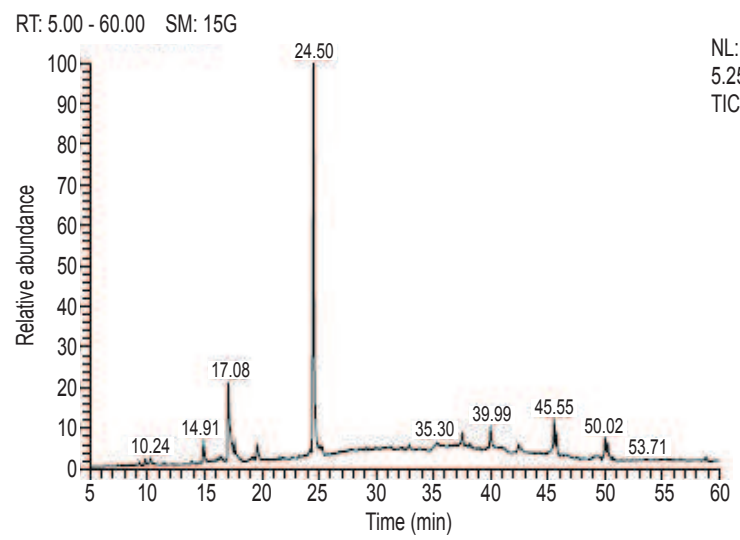

(c)

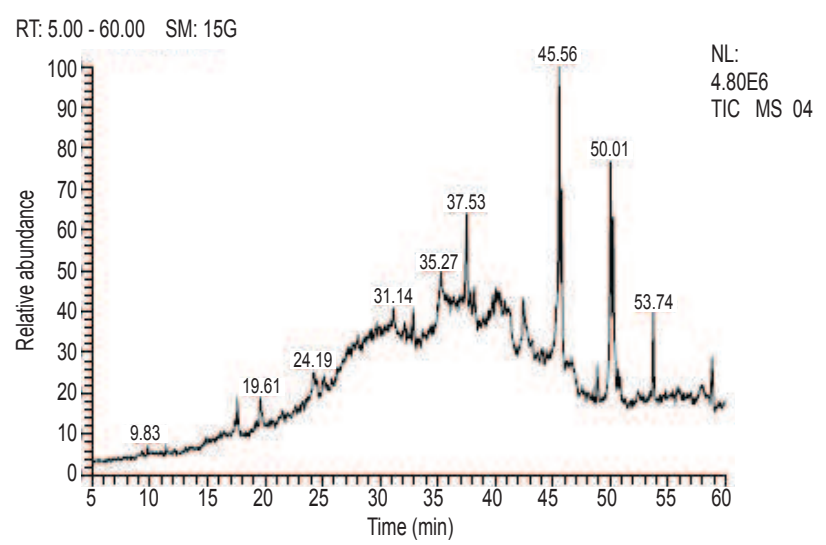

(e)

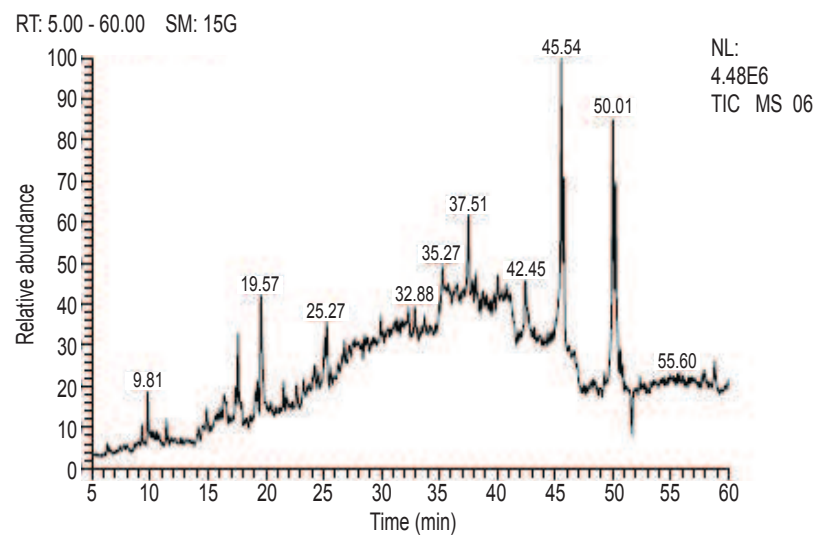

(b)

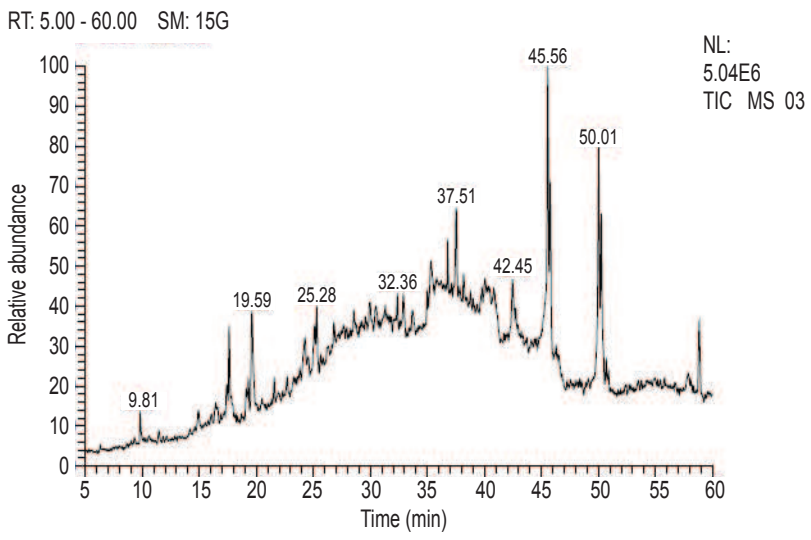

(d)

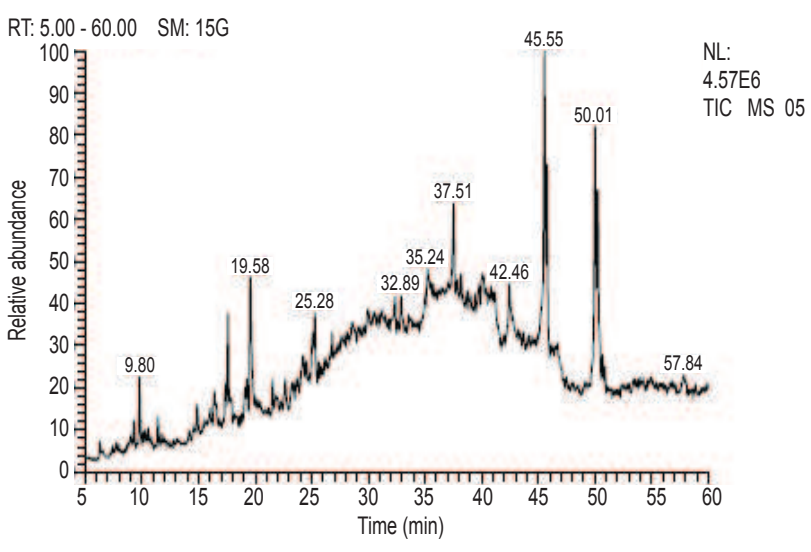

(f)

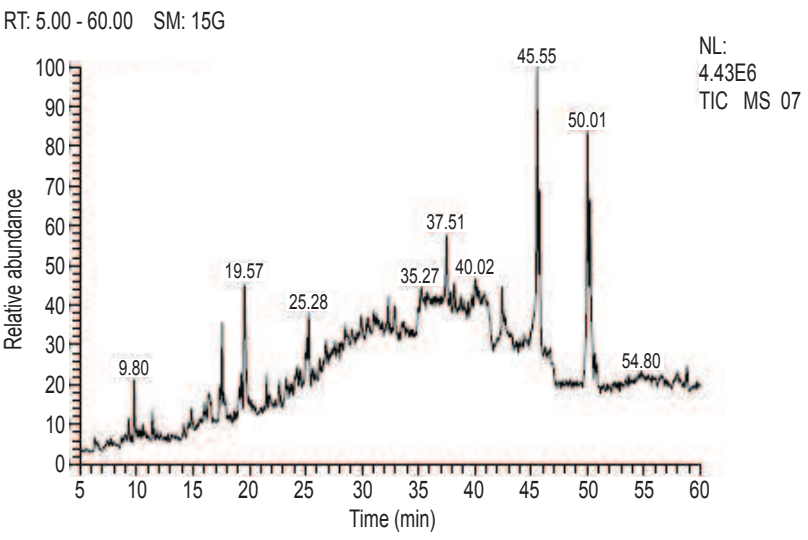

Figure 2. Chromatogram peak of plants, namely, A. conyzoides (a), A. gangetica (b), T. subulata (c), C. cobanensis (d), E. heterophylla (e), and A. leptopus (f).

\section{Structural Elucidation Unknown Compound Using GC-MS}

Terpenoids are the compounds that are generally thought to be insect attractants (Tholl et al., 2004). In this study using six species of plants, the terpenoids containing volatile compounds were detected as mentioned by Basri et al. (1999) who stated that several compounds have been identified in intact host plants nectars (sucrose, fructose and glucose).
For this study, the major constituents (48.45\%) included Trimethyl-3,4-methylenedioxychromane, Phenol,4,6-di(1,1-dimethylethyl)-2-methyl, and 2H1-Benzopyran, 6,7-dimethoxy-2,2-dimethyl-, whereas the minor constituents $(0.45 \%)$ were n-Hexadecanoic acid, Dodecanoic acid, 3-hydroxy-, and Octadecanoic acid, 2-(2-hydroxyethoxy) ethyl ester. According to Buchmann and Buchmann (1981) and Baker and Baker (1975), the host plant volatile compounds could attract predatory insects, 
where carboxylic acids, lipids and other organic compounds were also present in floral nectars. Besides that, the water element in nectar is also important to nectarivores (Willmer, 1986). Smilanick et al. (1978) reported field trials where acetaldehyde, ethyl acetate and ethyl alcohol were indicated as the principal attractants of Carpopilus hemipterus (Coleoptera: Nitidulidae) in California.

Volatile compounds are said to mediate many interactions between organisms, including plant response to pathogen infection (Shulaev et al., 1997), plant-parasitoid signalling in response to herbivory (Turlings et al., 1990) and plant-pollinator communication during flowering. As pollinator attractants, volatile compounds are the important cues that help insects to locate flowers and contribute to feeding and mating behaviours as well (Knudsen et al., 1993). Plants synthesise and emit a large variety of volatile organic compounds with terpenoids, fatty acids and derivatives as the dominant classes. Floral scent composition of a plant is thought to have evolved partly from adaptations towards the olfactory requirements of efficient pollinators. Some volatile compounds are probably very common to almost all plants while others are specific to only one or a few related taxa (Visser, 1986; Pichersky and Gershenzon, 2002).

Plant odour specificity is achieved by a characteristic ratio of the constituent chemical compounds, which are generally distributed among the plant species (Visser, 1986). Anthers and pollens release distinctive odours (Blight et al., 1995; Barkman, 2003) and floral volatile compounds are formed via plant biosynthetic pathways. The rapid progress in elucidating the biosynthetic pathways, enzymes and genes involved in the formation of plant volatiles allows their physiological activities and functions to be rigorously investigated at the molecular and biochemical levels. Floral volatiles act as attractants for species-specific pollinators. However, the volatiles emitted from the vegetative parts, especially those released after herbivory, protect plants by deterring herbivores and or attracting the enemies of herbivores (Pichersky and Gershenzon, 2002). Most of the floral fragrance compounds are terpenoids, simple aromatics, amines and hydrocarbons. The most common floral fragrance compounds are monoterpenes (Vickery and Vickery, 1981; Williams and Whitten, 1983).

There are suggestions on the use of beneficial plants for the improvement in the quality of natural enemies or beneficial insects (Van Emden, 1963; Altieri and Whitcomb, 1980; Tiong, 1982). Many researchers studied the parasitoid relationship with plants, while little research on predatory insects with plants. Leius (1967) reported on Umbelliferea species having carbohydrates content that is essential in the normal fecundity and longevity of three Icheumonid species. Meanwhile, Wolcott
(1941) reported that the successful establishment of the introduced parasitoid, Larra americana to control cricket depended on the presence of two weeds, Borreria verticillata and Hyptis atrorubens as these plants provided the nectar for the adult wasps in Puerto Rico.

\section{CONCLUSION}

Predatory insects have been known to respond to plant volatile. Our result indicated that the volatile from T. subulata, C. cobanensis, and A. leptopus attract $S$. dichotomus adults in cage experiments. To our knowledge, there are few reports on the response of $S$. dichotomus to different plant volatiles. Both sexes of the predatory insect highly preferred the odours emanating from $T$. subulata followed by $C$. cobanensis, and A. leptopus. Our finding provides new information on how to increase the predatory insects as a biological control agent in oil palm plantation. Stakeholders need to manage oil palm plantations by planting beneficial plants for predatory insect habitat.

\section{REFERENCES}

Altieri, M A and Whitcomb, W H (1980). Predacious and herbivorous arthropods associated with comphorweed (Heterotheca subaxillaris Lamb.) in north Florida. J. Georgia Entomology Society, 15: 290299.

Baker, H G and Baker, I (1975). Studies of nectar constitution and pollinator plant co-evolution. Animal and Plant Co-evolution (Gilbert, L E and Raven, P H eds.). University of Texas Press, Austin, Texas, USA. p. 100-140.

Barkman, T J (2003). Evidence for positive selection on the floral scent gene Isoeugenol-O-methyl transferase. Mol. Biol. Evol., 20: 168-172.

Barret, S C H (1978). Heterostyly in a tropical weed: The reproductive biology of the Turnera ulmifolia complex (Turneraceae). Can. J. Bot., 56: 1713-1725.

Basri, M W and Kevan, P G (1995). Life history and feeding behaviour of oil palm bagworm Metisa plana Walker (Lepidoptera: Psychidae). Elaeis, 7: 18-34.

Basri, M W; Siburat, S; Ravigedari, S and Othman, A (1999). Beneficial plants for the natural enemies of the bagworm in oil palm plantations. Proc. of the 1999 PORIM International Palm Oil Congress: Emerging Technologies and Opportunities in the Next Millennium. PORIM, Bangi. p. 165-179. 
Bernays, E A and Chapman, R F (1994). Host-plant Selection by Phytophagous Insects. Chapman and Hall, New York. p. 312.

Berndt, LA; Wratten, SD and Hassan, P (2002). Effects of buckwheat flowers on leafroller (Lepidoptera: Tortricidae) parasitoids in New Zealand vineyard. Agricultural and Forest Entomology, 4: 39-45.

Blight, M M; Pickett, J A; Ryan, K; Wadhiam, J and Woodack, K (1995). Recognition of oilseed rape volatiles by pollen beetles Meligethes spp: electrophysiological and chemical studies. Proc. of the $9^{\text {th }}$ International Rapeseed Congress (Murphy, D C ed.). Vol. III. Cambridge University Press, United Kingdom. p. 1043-1045.

Buchmann, S L and Buchmann, M D (1981). Anthecology of Mouriri myrtilloides (Melastomatacea: Memecyleae) an oil flower in Panama. Biotropical (Reproductive Botany Supplement), 13: 7-24.

Chaney, W E (1998). Biological control of aphids in lettuce using in-field insectaries. Enhancing Biological Control: Habitat Management to Promote Natural Enemies of Arthropod Pests (Pickett, C H and Bugg, $\mathrm{R}$ L eds.). University of California Press, Berkeley, USA. p. 73-83.

Chung, G F (1989). Spraying and trunk injection of oil palm for pest control. The Planters, 65: 500-524.

Gonzalez-teuber, M and Heil, M (2009). Nectar chemistry is tailored for both attraction of mutualists and protection from exploiters. Plant Signal Behav., 4: 809-813.

Heil, M (2011). Nectar: Generation, regulation and ecological functions. Trend Plant Sci., 16: 191-200.

Hickman, J M and Wratten, SD (1996). Use of Phacelia tanacetifolia strips to enhance biological control of aphids by hoverfly larvae in cereal fields. J. Economic Entomology, 89: 832-840.

Ho, C T; Khoo, K C; Ibrahim, Y and Omar, D (2003). Comparative studies on the use of beneficial plants for natural suppression of bagworm infestations in oil palm. Proc. of the PIPOC 2003 International Palm Oil Congress - Agriculture Conference. MPOB, Bangi. p. 372-424.

Hoffman, M P and Frodsham, A C (1993). Natural Enemies of Vegetable Pest Insects. Cornell Cooperative Extension Publications, New York, USA. p. 63.

Irvin, N A; Wratten, S D and Frampton, C M (2000). Understory management for the enhancement of the leafroller parasitoid Dolichogenidea tasmanica
(Cameron) in orchards at Canterbury, New Zealand. Hymenoptera: Evolution, Biodiversity and Biological Control, (Austin, A D and Dowton, M eds.). CSIRO Publishing Collingwood, Victoria, Australia. p. 396403.

Jamian, S; Ahmad, N; Ghazali, A; Zakaria, A and Azhar, B (2017). Impacts of two species of predatory Reduviidae on bagworms in oil palm plantations. Insect Science J., 24: 285-294.

Jamian, S and Nur Azura, A (2018). The performance of predatory insect, Sycanus dichotomus Stal. (Hemiptera: Reduviidae) on combination of plant host and prey. Serangga: 23(2): 56-64.

Jervis, M A; Kidd, N A C and Heimpel, G E (1996). Parasitoid adult feeding behaviour and biocontrol A review. Biocontrol News and Information, 17: 11-26.

Knudsen, J T; Tollsten, L and Bergström, G (1993). Floral scents, a checklist of volatile compounds isolated by headspace techniques. Phytochemistry, 33: 253-280.

Kroon, H (2009). Biology of Lilioceris lilii (Coleoptera: Chrysomelidae) and the Occurrence of their Parasitoids in Sweden. Master thesis. Swedish University of Agricultural Sciences, Alnarp, Sweden. p. 45.

Leena, A I and Hazem, S H (2011). Bioresidual effect of two insecticides on melon aphids Aphiss gossypii Glover (Homoptera: Aphididae) and its parasitoid Aphidius colemani Verick (Hymenoptera: Brachonidae). American-Eurasian J. Agriculture and Environmental Science, 11: 228-236.

Leius, K (1967). Influence of wild flowers on parasitism of tent caterpillar and codling moth. Canadian Entomologist, 99: 444-446.

Liu, T; Amin, S; Zha, H; Mohsin, M and Ishtiaq, M (2013). Floral nectar composition of an outcrossing bean species Mucuna sempervirens Hemsl (Fabaceae). Pak. K. Bot., 45: 2079-2084.

Noor Farehan, I; Syarafina, R and Idris, A B (2013). Toxicity of three insecticides on the predator of oil palm leaf-eater pests Sycanus dichotomus Stal. (Hemiptera: Reduviidae). J. Entomology, 6: 1119.

Noor Hisham, H and Sukri, T B (2004). Ancaman serangan ulat pemakan daun yang berterusan di ladang sawit. Kemajuan Penyelidikan Bil. 42. p. 19-25.

Norman, K and Basri, MW (2007). Status of common oil palm insect pest in relation to technology adoption. The Planter, 83: 371-385. 
Norman, K and Basri, M W (2010). Interactions of the bagworm, Pteroma pendula (Lepidoptera: Phsycidae), and its natural enemies in an oil palm plantation in Perak. J. Oil Palm Res. Vol. 22: 758-764.

Pichersky, E and Gershenzon, J (2002). The formation and function of plant volatiles: Perfumes for pollination attraction and defense. Curr. Opin. Plant Biol., 53: 237-243.

Schlindwein, C and Medeiros, P C R (2006). Pollination in Turnera subulata (Turneraceae): Unilateral reproductive dependence of the narrowly oligolectic bee Protomeliturga turnerae (Hymenoptera, Andrenidae). Flora, 201: 178-188.

Shulaev, V; Silverman, P and Raskin, I (1997). Airborne signaling, by methyl salicylate in plant pathogen resistance. Nature, 385: 718-721.

Sing, S (1986). The use of electrical drills for more efficient trunk injection against bagworms in oil palms. The Planters, 62: 54-57.

Smilanick, J M; Ehler, L E and Birch, M C (1978) Attraction of Carpophilus spp. (Coleoptera: Nitidulidae) to volatile compounds present in figs I. J. Chem. Ecol., 4: 701-707.

Tholl, D; Chen, F; Gershenzon, J and Pichersky, E (2004). Arabidopsis thaliana, a model system for investigating volatile terpene biosynthesis, regulation and function. Secondary Metabolism in Model System (Remoe, J T ed.). Amsterdam, Elsevier. p. 1-18.

Tiong, R H C (1982). Oil palm pests in Sarawak and the use of natural enemies to control them. Proc. of the International Conference Plant Protection in Tropics (Heong, K L; Lee, B S; Lim,T M; Teoh, C H and Yusof, I eds.). Malaysian Plant Protection Society, Kuala Lumpur. p. 363-372.
Turlings, T C J; Tumlinson, J H and Lewis, W J (1990). Exploitation of herbivore induced plant odors by host seeking parasitic wasps. Science, 250: 1251-1253.

Van Emden, H F (1963). Observations of the effects of flowers on the activity of parasitic Hymenoptera. Entomologist's Monthly Magazine, 98: 265-270.

Vickery, M L and Vickery, B (1981). Secondary Metabolism. London, Macmillan Press. p. 335.

Visser, J H (1986). Host odor perception in phytophagous insects. Ann. Rev. Entomol., 31: 121124.

Williams, N and Whitten, W M (1983). Orchid floral fragrances and male euglossine bees: Methods and advances in last sesquidecade. Biological Bulletin, 164: 355-395.

Willmer, P (1986). Foraging patterns and water balance: Problems of optimization for a xerophilic bee, Chalicodoma sicula. J. Anim. Ecol., 55: 941-962.

Wolcott, G N (1941). The establishment in Puerto Rico of Larra americana Saussure. J. Econ. Entomology, 34: 53-56.

Wood, B J and Nesbit, D P (1969). Caterpillar outbreaks on oil palms in Eastern Sabah. The Planter, 45: 285-299.

Yusdayati, R (2008). Biological and Ecological Aspects of Bagworms (Lepidoptera: Psychidae) in Ladang FELDA, Sungkai, Perak Emphasizing on Increasing Efficiency of Natural Enemies through Planting of Beneficial Plants. Master thesis. Universiti Sains Malaysia. p. 157.

Yusdayati, R, Ahmad, A H and Hamid, N H (2014). Diversity and distribution of natural enemies (predators and parasitoids) of bagworms (Lepidoptera: Psycidae) on selected host plants in an oil palm plantation. The Planters, 90: 91-101. 